UDC 821.163.41.09 Vidaković M.

https://doi.org/10.18485/ms_zmskij.2021.69.2.8

Др Радослав Љ. Ераковић

\title{
ТАМО И НАТРАГ: НЕОЧЕКИВАНО ПУТОВАЬЕ ТОВИЈЕ ИЗ НИНИВЕ
}

Књижевно стваралаштво Милована Видаковића (1780-1841) предуго је вредновано на начин због којег можемо констатовати да је читалачка публика била много више наклоњена славеносрпском аутору, него проучаваоци српске деветнаестовековне књижевности. Наше претходно запажање засновано је на резултатима дијахронијске и синхронијске анализе релевантних књижевнокритичких и књижевноисторијских радова, посвећених прозном и песничком стваралаштву једног од најпопуларнијих предромантичарских писаца. Мада је репутацију талентованог сочинииеељ $a$ стекао захваљујући својим романима попут Љубомира у Јелисијуму (Видаковић 1814; Видаковић 1817; Видаковић 1823), никако не би требало занемарити чињеницу да је Милован Видаковић један од најплоднијих и најсвестранијих српских предромантичарских песника, о чему врло јасно сведочи податак да је објавио чак четири религиозна епа (Видаковић 1805; Видаковић 1825; Видаковић 1834; Видаковић 1839). У овом тексту ћемо посебну пажњу посветити поетичким, тематским и жанровским особеностима његовог песничког дела инспирисаног старозаветном (деутероканонском) приповешћу о пустоловинама Товије из Ниниве. Ослањајући се на сопствено истраживачко и херменеутичко искуство, покушаћемо да објаснимо због чега сматрамо да ниједно друго поетско-епско остварење злосрећног славеносрпског полихистора није толико отворено за савремена тумачења као његов „архаични“ религиозни еп Млаgи Товија (Видаковић 1825).

Кључне речи: Милован Видаковић, Џ. Р. Р. Толкин, еп, роман, хронотоп путовања, славеносрпска епоха, српски предромантизам

Посматрано из савремене књижевноисторијске перспективе, нема никакве сумње да је умеће Џ. Р. Р. Толкина (1892-1973) у обликовању имаги- 
нарних језичких кодова одиграло веома значајну улогу у настанку Хобий (TolKIEN 1937), Госйоgара йрсиеенова (TOLKIEN 1954; 1955) и Силмарилиона (ToLKIEN 1977). Колико год то деловало необично, управо нас је општепознато лингвистичко обележје Толкинових приповедачких светова учврстило у уверењу да је језик којим говоре јунаци Милована Видаковића ништа мање необичан савременим српским читаоцима од вилењачког говора Средње земље. Кьижевно стваралаштво Милована Видаковића (1780-1841) оцењивано је, током претходна два века, на начин због којег с неподношљивом лакоћом можемо констатовати да је читалачка публика била много више наклоњена аутору Љубомира у Јелисијуму (Видаковић 1814; 1817; 1823) него проучаваоци српске деветнаестовековне књижевности. Наше претходно запажање засновано је на спознаји о драстичним разликама у вредновању опуса Милована Видаковића, које можемо запазити приликом дијахронијске анализе релевантних књижевнокритичких и књижевноисторијских радова, објављених у периоду између 1815. и 2018. године. За разлику од најпознатијих скептичних тумача Видаковићевог стваралаштва - међу којима се посебно издвајају „непристрасни“ Вук Караџић (КАРАџић 1815; 1817), „непогрешиви“"Павле Поповић (Поповић 1934) и амбивалентни Јован Деретић (ДЕРетит 1980) - књижевни историчари попут Саве Дамјанова (ДАмјАнов 1987; 1988), Милорада Павића (ПАвић 1991) и Срђана Орсића (Орсић 2018) аргументовано су доказали због чега најпопуларнијем предромантичарском писцу (ипак) није место у својеврсном лимбу српског књижевног наслеђа.

Као што смо већ наговестили у уводном сегменту овог текста, историја рецепције стваралаштва славеносрпског сочинитеељ $a$ није ништа мање компликована од заплета његовог Љубомира у Јелисијуму (ВидАковић 1814; $1817 ; 1823)$, нарочито ако узмемо у обзир романескни карактер Видаковићеве полемике са „мистериозним“ сарадником Новина сербских ([КАРАџић] $1815 ;$ 1817). Упркос томе што у традиционалним токовима српске књижевне историографије никада није постигнут консензус око аутентичности стваралачког израза Милована Видаковића, пажљивије упоредно ишчитавање радова претходно наведених аутора упућује на претпоставку о (не)очекивано високом степену сагласности његових блайоразумних чийайеља, око тога да романескна проза представља најзначајнији сегмент жанровски хетерогеног опуса даровитог славеносрпског књижевника. Ипак, књижевно-

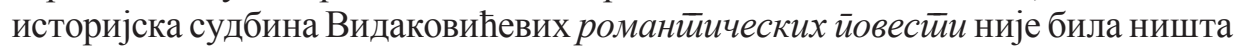
мање невесела од оне која је задесила његове религиозне епове, пре свега зато што је процес реактуелизације његових библических йовестии во стии$x u$ такође отпочео тек крајем 20. и почетком 21. века (ДАмјАнов 1988; ПАвит 1991; ЕРАКовић 2008). С обзиром на то да аутор овог текста такође припада малобројној али повлашћеној групи савремених проучавалаца поетско-епских сочиненија Милована Видаковића, веома смо захвални Уредништву Зборника Майице срйске за књижевности и језик на томе што нам је пружена прилика да се поново посветимо Видаковићевом песништву, јер је 
управо то истраживачка тема због које смо се - пре тачно две деценије заинтересовали за научни и архивски рад.

Мада је репутацију талентованог писца стекао захваљујући романима, никако не би требало занемарити чињеницу да је Милован Видаковић један од најплоднијих и најсвестранијих српских предромантичарских песника, о чему врло јасно сведочи библиографски податак да је написао и објавио чак четири религиозна епа (ВидАковић $1805 ; 1825 ; 1834 ; 1839)$. Међутим, у овом тексту ћемо пре свега размотрити одређене поетичке, тематске, па чак и жанровске особености његовог песничког дела инспирисаног старозаветном (деутероканонском) приповешћу о пустоловинама Товије из Ниниве (ВидАковић 1825). Како бисмо на текстолошки аргументован начин објаснили зашто је отклањање предрасуда о славеносрпској епоси толико значајно за савремено проучавање наше богате књижевне баштине, у наредном сегменту овог рада ћемо се осврнути на Видаковићеве аутопоетичке исказе из предговора првом издању Млаgо̄ Tовије (Видаковић 1825: III-VI). Детаљна анализа пишчевог йреgисловија без сваке сумње потврђује исправност тезе о рецепцијској привлачности предромантичарских поетско-епских остварења, инспирисаних библијском и средњовековном хагиографском традицијом. Међутим, много је значајнија чињеница да је аутор Млаgо̄ Toвије имао веома јасну представу о читалачким афинитетима српске публике почетком деветнаестог века (ВидАковић 1825: III-IV). С обзиром на то да смо већ у уводном делу текста „дискретно“ подсетили на незавидан статус Видаковићевог литерарног опуса у традиционалним токовима српске књижевне историографије, никако не би требало да нас изненади податак да је пишчево истицање порекла примарног предлошка (пре)дуго анализирано на позитивистички педантан и чињенично непоуздан начин.

На пример, ауторово инсистирање на библијском пореклу основног тематског оквира Mлаgог Tовије (ВидАковић 1825: IV), Павле Поповић је у својој чувеној монографији представио као необорив доказ о надриучености Милована Видаковића (Поповић 1934: 293-295). Павле Поповић је инсистирао на тези да изворна старозаветна приповест није могла бити позната Миловану Видаковићу и српским читаоцима из прве половине деветнаестог века, при чему је угледни српски научник занемарио канонски и културолошки значај вишевековних расправа о разликама између „,александријског“и „палестинског" корпуса старозаветних текстова. ${ }^{1}$ Према његовој сугестивној (псеудо)биографској интерпретацији околности у којима је настало анализирано дело Милована Видаковића, прича о Товији је почетком деветнаестог

1 „За потребе александријских Јевреја извршен је превод светих књига на грчки језик (такозвана Септуагинта) у времену од око 250 . до око 100 . године. У том преводу се налазе књиге и делови неких књига, којих, касније, неће бити у палестинском канону. То су: Књига Варухова, Књига о Товији, Књига о Јудити, 1. и 2. Макавејска, Премудрости Соломонове, Премудрости Исуса сина Сирахова и делови: Дан 3, 24-90, 13. и 14. гл. и Јест 10, 4-16,24“ (Милин 1991: 67-77). 
века могла доспети у нашу литературу искључиво под утицајем другоразредних аутора побожних спевова, насталих на немачком говорном подручју (Поповић 1934: 294). Дужни смо да истакнемо како је оштар критички став Павла Поповића био првенствено заснован на текстолошкој замерки да приповести о Товији из Ниниве нема у „нашој Библији“ (Поповић 1934: 294). Данас је више него оправдано претпоставити да се његова напомена о „нашој Библији“" односила на превод $C \bar{u} а р о \bar{\imath}$ завет̄ $a$ Ђуре Даничића (ДАничић $1865 ; 1868)$, у којем није објављена Къйа о Товији зато што се славни српски филолог ослонио на латински превод старозаветних текстова Имануела Тремелиуса (ЕРАковић 2008: 64). Међутим, теза о ограниченом присуству одређених старозаветних тема у српској култури и књижевности, може бити врло лако оспорена освртом на поетско-епско стваралаштво угледних савременика Милована Видаковића, попут земунског песника и књижара Гаврила Ковачевића (1765-1832), чији је религиозни еп о старозаветној хероини Јудити такође био надахнут догађајима који нису описани у „нашој“ Библији (КовАЧЕВИЋ 1808).

Разрешење ове интертекстуалне енигме потврђује тачност тезе о тексту као кондензатору културног памћења (ЛотмАн 2004: 26). Наиме, захваљујући издавачком подухвату енергичног митрополита Стефана Стратимитовића (1757-1836), савременицима Милована Видаковића било је доступно петотомно издање Словенске Библије на рускоцрквенословенском језику, које садржи поглавље посвећено судбини праведног Товита и његове побожне породице (СтРАтимиРовић 1804). Анегдотски карактер фактографског пропуста, који је направио један од наших најугледнијих књижевних историчара из прве половине двадесетог века, представља драгоцено сведочанство о томе како су стваране стереотипне представе не само о стваралачким, него и о теолошким компетенцијама славеносрпских сйисайеља. Сагледано из савремене истраживачке перспективе, луцидни аутопоетички коментари Милована Видаковића, посвећени процесу настанка Mлаgої Tовије, нису ништа мање релевантни за тумачење поезије српског предромантизма од „програмског“ текста песника Јована Дошеновића (1781-1813), објављеног у форми предговора првом издању његове песничке збирке Лирическа ӥјенија (Дошеновић 1809: [I-XVIII]).

У уводном сегменту овог текста смо већ навели да је Милован Видаковић, између 1805. и 1839. године, написао четири религиозна епа, што се хронолошки поклапа с периодом највеће популарности побожних спевова, писаних и штампаних на славеносрпском језику. Да будемо сасвим прецизни, два његова најобимнија епа била су инспирисана пустоловинама Јосифа Прекрасног и Товије из Ниниве (ВидАковић 1805; 1825), једно йобожно gелце настало је на основу новозаветног описа Исусовог првог боравка у Јерусалиму (ВидАковић 1834), а његово последње поетско-епско остварење било је надахнуто ранохришћанском легендом о витешком подвигу Светог Ђорђа (ВидАковић 1839). Пишчева читалачка и стваралачка наклоност према старозаветним темама нас је навела да претпоставимо како је доказе о 
високом степену жанровске кохерентности Видаковићевог песништва вероватно најлакше синтетизовати кроз упоредно ишчитавање Исйорије o ирекрасном Јосифу (Будим 1805) и Млаgо̄ Товије (Будим 1825), што нас је довело до закључка како постоје недовољно истражене тематске линије додира, између ова два остварења Милована Видаковића. Наиме, Јосиф и Товија су „багинсовски“ неприпремљени за неочекивано и опасно путовање, које ће их одвести у далеке и егзотичне пределе (љубоморна браћа су очевог љубимца Јосифа продала трговцима робљем за двадесет сребрњака, а Товија одлази из Ниниве у Екбатан како би избавио оца од сиромаштва и тешке болести). Двојица старозаветних адолесцената очигледно нерадо напуштају место одрастања, након чега се веома брзо суочавају са спознајом како их дотадашњи начин живота није припремио за многобројна физичка, духовна, па чак и криптоеротска искушења. Упркос томе што је предромантичарски чувсиивииеелним описима синовљеве привржености оцу припало истакнуто место у прологу и епилогу оба епа, мотив очинске љубави не може бити сврстан међу конститутивне елементе тематске структуре Млаgō̄ Toвије. Након пажљивијег ишчитавања наведеног дела, постаје јасно да су улоге кључних протагониста додељене двојици најмлађих јунака, а не њиховом ослепелом сроднику и „плачевном“ праведнику Товиту (ВидАковић 1825: 43). Осим тога, утицај доситејевски благоглагољивог Товита на главни ток догађаја је маргинализован у мери која упућује на закључак о првом упадљивом тематском одступању анализираног песничког текста, у односу на примарни библијски предложак.

Наше претходно запажање о функцији одређених ликова у композицији дела, иницирано је резултатима анализе (идеализоване) социјалне интеракције Товије и његовог загонетног заштитника Азарије, чији се прави идентитет на сценски импресиван начин открива тек у епилогу Mлаgо̄ Товије (ВидАковић 1825: 111-112). Према нашем мишљењу, поступно зближавање двојице актера опасног йуиещестивија афирмише тезу о доминацији култа сентименталног пријатељства у Видаковићевој литерарно уобличеној авантури двојице јуноща из племена Нефталимовог (ВидАКовић 1825: 28-29). Посматрано из шире дијахронијске перспективе, детерминисање општих тематских карактеристика стваралачког опуса Милована Видаковића такође указује на веома значајну разлику између Млаgог Товије и осталих поетско-епских сочиненија наведеног аутора. Наш исказ је заснован на чињеници да су изасланици Више силе једино у овом Видаковићевом епу непосредни учесници најважнијих догађаја, у свакодневном животу „повлашћених“ смртника. Претпоставка о присуству недовољно истраженог дистинктивног обележја је проистекла из анализе кључних поступака и реакција Товијиног мистериозног сапутника Азарије, односно „ангела Рафаила“ (Видаковић 1825: 107). Дивинизирана природа Товијиног „сопутника“ (ВидАковит 1825 : 30) доводи нас до својеврсне херменеутичке дилеме, коју ћемо покушати да разрешимо већ у следећем сегменту нашег рада. Наиме, потпуно смо свесни у којој мери је оправдана (хипотетичка) критичка примедба да се прерушени 
анђео у прологу дела представља слепом Товиту као брижни рођак, а не као случајни пријатељ инфантилно лаковерног Товије (ВидАковић 1825: 33-34). Међутим, дискутабилна генеалошка дилема не може оспорити нашу тезу о поетичкој супремацији култа сентименталног пријатељства у Млаgом Товији. Једноставно, услед тога што Азарији није допуштено да открије свој идентитет пре повратка у Ниниву, ништа друго осим инсистирања на наводним родбинским везама није могло отклонити Товитове сумње у намере странца који се, сасвим неочекивано, понудио да буде водич Товитовом (наивном) сину.

Уосталом, могли бисмо претпоставити да би чак и потпуно неупућени читалац - уз услов да се први пут упознаје са библијском причом о Товији и његовом анђелу заштитнику - морао посумњати у сродство између двојице младића. За разлику од одважног путовође Азарије, мајчино „љубезно јединче“" Товија (ВидАковић 1825: 18) нема ништа заједничко са својим старозаветним саплеменицима и славним ратницима, попут Гедеона сина Јоасовог и Јуде Макавеја. Наравно, аутор Млаgо̄ Товије се могао определити - приликом обликовања тематске структуре епа-за рецепцијски привлачан поступак интенционалне хероизације главног протагонисте (Бахтин 1986: 716). С обзиром на статус лика андрогине ратнице Косаре у првом делу романа Љубомир у Јелисијуму (ВидАКовић 1814), можемо констатовати да поменута наратолошка техника свакако није представљала непознаницу за Милована Видаковића. Међутим, изненадан и необјашњив (психофизички) преображај младог јунака, проузроковао би кршење кључних жанровских и поетичких конвенција, детаљно описаних управо у предговору Млаgом Товији (ВидАковић 1825: III-VI). Без обзира на Азаријино реторски вешто уобличено инситирање на сопственој добронамерности (посебно током првог сусрета са сумњичавим Товитом), убиство гренделовског воденог чудовишта и тријумфална победа над демоном Асмоадом отклањају сваку дилему око тога коме је припала улога хероја у сочиненију Милована Видаковића (месопотамијска неман из Млаgоі Товије има идентичну архетипску функцију као Шмауг у Хобийу или Балрог у Госйоgару йрсиеенова, јер авантура не може бити настављена пре него што „метафоричка“ манифестација зла не буде поражена). Према нашем мишљењу, инвентивну идентитетску трансформацију Азаријиног лика, требало би интерпретирати као последицу још једног тематског одступања анализираног дела, у односу на старозаветни предложак. Детаљна анализа фабулативно-сижејне структуре Mлаgō Toвије, указује на доследну маргинализацију сакралних аспеката примарног предлошка, заснованих на континуираном истицању анђелове догматске супериорности у односу на чланове Товитове породице (Азарија из Mлаgо̄ Tовије због тога много више подсећа на Торина Храстоштитог, Леголаса и Арагорна, него на библијске етеричне анђеле-гласнике).

Припадник небеске хијерархије у религиозном епу Милована Видаковића није описан „само“ као узвишени изасланик Више силе, чији је једини задатак да процени у којој мери је puer aeternus из Ниниве достојан Јахвеове 
милости. За разлику од (све)моћног херувима, Азаријин лик представљен је читаоцима Млаgо̄ Товије као пустолов-луталица и прогонитељ демонских сила (старовековним редакторима Септуагинте вероватно је било јасно да се безазлени Товитов син никада не би вратио кући без помоћи телохранитеља, баш као што ни Толкинова дружина јешних Хобита не би одмакла даље од границе Округа без Арагорнове заштите). Посматрано из савремене књижевноисторијске перспективе - која нас подстиче да занемаримо формалне жанровске и стилске разлике између „архаичних“ религиозних епова и „модерне“ епске фантастике - сматрамо да смо у претходним сегментима текста доказали како је хронотопу путовања припала готово идентична (повлашћена) функција у фикционалним световима Џ. Р. Р. Толкина и Милована Видаковића. Према томе, без обзира на то што је Толкинова опсесивна посвећеност проучавању нордијске митологије и староенглеске књижевности пресудно утицала на обликовање сижејне структуре његових романа (TOLKIEN 1963; КАРПЕНTEP 2012; ХАНРАХАн 2012), сасвим је разумљиво због чега нас Товијино неочекивано и опасно путовање толико асоцира на авантуре Фрода и Билба Багинса. Мада би конзервативни бирмингемски римокатолик попут Толкина вероватно био констерниран идејом о многобројним итеролошким подударањима између Средњег истока и Средње земље, верујемо да су наша „бласфемична“ запажања - посебно она о (ин) дискретној тематској блискости анализираних књижевних текстова - потврдила херменеутичку вредност претпоставке о могућностима новог читања

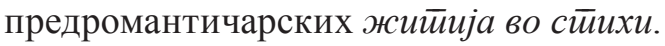

Према моделу који смо применили приликом иницијалне класификације проблемских целина од посебног значаја за анализу Малог Товије (интерпретација аутопоетичких исказа и детерминисање општих обележја сижејне структуре дела), резултате нашег истраживања представићемо у оквиру два кратка сегмента. Дијахронијско и синхронијско проучавање тематски разноврсних йреgисловија и ирримечанија, односно текстова који не представљају део интегралне структуре романа и религиозних епова Милована Видаковића, довело нас је до закључка да аутопоетички искази пружају драгоцене информације о стваралачком поступку злосрећног славеносрпског полихистора. Ипак, само резултати детаљног ишчитавања примарног текста, могу оправдати позитивно естетско вредновање стваралаштва скрајнутих славјаносербских аутора. Упоредимо ли Млаgог Товију са осталим жийијима во сииихи Милована Видаковића, можемо констатовати да је десакрализација припадника небеске хијерархије успешно реализована једино у литерарно уобличеним пустоловинама Товије и Азарије. Улога наведеног дистинктивног обележја у проучавању феномена позитивне рецепције је евидентна, зато што је писац много већу пажњу поклонио популарности авантуристичких животописа старозаветних ироја (сва водена и подземна чудовишта су поражена, а Товија је награђен браком с гамофобичном лепотицом Саром), него њиховом догматском статусу у јудеохришћанској традицији. Процес дезинтеграције традиционалних тематско-мотивских 
аспеката, иницирао је стварање ликова који - упркос сличностима с библијским прототиповима - представљају плод пишчеве канонским нормама неспутане имагинације. Управо нас је то охрабрило да постанемо заступници теорије о хронотопичним подударањима између два дела, посебно када је у питању начин на који становници Видаковићевих и Толкинових приповедачких светова путују и извршавају тешке задатке.

На крају, желели бисмо да уверимо потенцијалне читаоце овог текста како постоје бројне стазе кроз шуму симбола, којима би могли да се запуте будући проучаваоци богатог књижевног наслеђа „предвуковске“ епохе. На пример, психолошки уверљива карактеризација ликова младих пустолова, довела нас је до претпоставке да би савремена истраживања Безимене (Радичевић 1923) требало усмерити у правцу потраге за жанровским линијама додира између недовршеног романа у стиховима Бранка Радичевића (18241853) и композицијски много хомогенијег религиозног епа Милована Видаковића (ВидАковић 1825). Ослањајући се на сопствено читалачко искуство - стечено током вишегодишњег проучавања занемареног тока српског деветнаестовековног песништва - искористићемо прилику да још једном истакнемо како се отвореност одређеног књижевног дела за нова читања никада више не би смела (априорно) оспоравати, само због тога што је написано на „,архаичном“ и „неразумљивом“ славеносрпском језику. На основу свега претходно наведеног, одлуку уредништва престижног научног часописа да приреди овај темат, требало би протумачити као доказ да негативне стереотипне представе о славеносрпској језичкој и књижевној баштини коначно одлазе у заслужени заборав.

\section{ИЗВОРИ И ЦИТИРАНА ЛИТЕРАТУРА}

БАхтин, Михаил. Еп и роман: о методологији изучавања романа. Леӣойис Майице срйске CLXII/437 (1986): 711-724; 903-919.

ВидАковић, Милован. Иситорија о иррекрасном Јосифу. Будим: Славено-србска печатња Краљевскаго всеучилишта венгерскаго, 1805.

ВидАковић, Милован. Љубомир у Јелисијуму [Част̄ I]. Будим: Славено-србска печатња Краљевскаго всеучилишта венгерскаго, 1814.

ВидАковић, Милован. Љубомир у Јелисијуму или Свет̄озар и Драїиња [Част̄ II]. Будим: Славено-србска печатња Краљевскаго всеучилишта венгерскаго,1817.

ВидАковић, Милован. Љубомир у Јелисијуму или Свет̄озар и Драйиња [Части III]. Будим: Славено-србска печатња Краљевскаго всеучилишта венгерскаго,1823.

ВидАковић, Милован. Млаgи Товија. Будим: Славено-србска печатња Краљевскаго всеучилишта венгерскаго, 1825.

Видаковић, Милован. Пуйещестивије у Јерусалим. Будим: Славено-србска печатња Краљевскаго всеучилишта венгерскаго, 1834. 
Видаковић, Милован. Песн ироическа о свјайом великомученику Георйију. Нови Сад: П. Јанковић, 1839.

Дамјанов, Сава. Видаковић, модернији од Вука. Поља 342/343 (1987): 332-336.

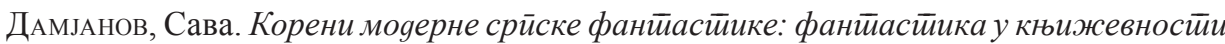
срӣской ирреяроманӣизма. Нови Сад: Матица српска, 1988.

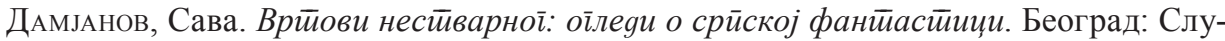
жбени гласник, 2011.

ДамјАнов, Сава. Нова чийања ӣраquщије. Београд: Службени гласник, 2012.

Даничић, Ђура [прев.]. Свеӣо йисмо. Пешта: Издање А. Рајхарда и друга му, 1865.

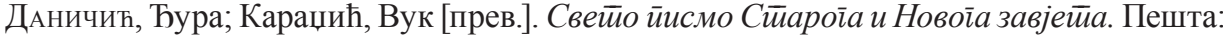

Штампарија Хорњанскога и Трегера, 1868.

Деретић, Јован. Вияаковић и рани срӣски роман. Нови Сад: Матица српска, 1980.

Дошеновић, Јован. Лирическа ӥјенија. Будим: Славено-србска печатња Краљевскаго всеучилишта венгерскаго, 1809, [I-XVIII]

Ераковић, Радослав. Релиїиозни ей срӣской ӥреgроманӣизма. Нови Сад: Матица српска, 2008.

КАлЕзић, Димитрије [гл. уред.]. Енщиклойеgија ӥравославља. Београд: Савремена администрација, 2002.

[КАРАџић, Вук]. Рецензија о књизи зовомој: Усамљениј јуноша. Новине сербске бр. 205-206 и 208 (1815): 819-820; 823-824; 831-832.

[КАРАџић, Вук]. Друга рецензија србска. Љубомир у Јелисијуму от Милована Видаковича, Новине сербске бр. 57-68 (1817): 453-456; 461-464; 469-472; 477-480; 485-488; 493-496; 501-504; 517-520; 525-528; 533-536; 541-544.

КАрПентеР, Хамфри. ЦІ. Р. Р. Толкин: биоірафија. Београд: Албион букс, 2012.

КовАчевић, Гаврило. Jуgит̄ мечем Олоферну ілаву усекнувщи йем Jуgеју освободив$\underline{u}$ u. Будим: Славено-србска печатња Краљевскаго всеучилишта венгерскаго, 1808

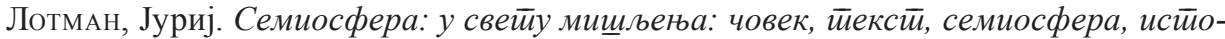
рија. Нови Сад: Светови, 2004.

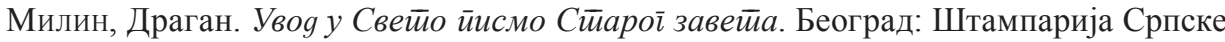
патријаршије, 1991.

Орсић, Срђан. Лик сйранца у срйском роману 19. века. Загреб; Даљ: Српско културно друштво „Просвјета“; Културни и знанствени центар „Милутин Миланковић“, 2018.

ПАвић, Милорад. Предроманӣизам. Београд: Научна књига, 1991.

Поповић, Павле. Милован Виgаковић. Београд: Издавачко и књижарско предузеће Геца Кон, 1934.

РАдичевић, Бранко. Песме [средио Т. Остојић]. Београд: И. Ђ. Ђурђевић, 1923.

Стратимировић, Стефан [изд.]. Библија сирјеч книїи свјащченайо йисанија Вейха̄̄o и

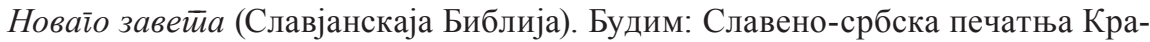
љевскаго всеучилишта венгерскаго, 1804. 
Tolkien, J. R. R. The Hobbit. London: George Allen and Unwin, 1937.

Tolkien, J. R. R. The Fellowship of the Ring. London: George Allen and Unwin, 1954.

Tolkien, J. R. R. The Two Towers. London: George Allen and Unwin, 1954.

Tolkien, J. R. R. The Return of the King. London: George Allen and Unwin, 1955.

Tolkien, J. R. R. The Silmarillion [ed. C. Tolkien]. London: George Allen and Unwin, 1977.

Tolkien, J. R. R. Beowulf: The Monsters and the Critics. In Lewis E. Nicholson [ed.]. An

Anthology of Beowulf Criticism. South Band: University of Notre Dame Press (1963): 51-103.

Ханрахан, Гарет. Толкинов свей: воgич кроз Среgњу землу и њене нароgе. Београд: Алнари, 2012.

Radoslav Lj. Eraković

THERE AND BACK AGAIN:

AN UNEXPECTED JOURNEY OF TOBIAS FROM NINEVEH

Summary

Milovan Vidaković's (1780-1841) literary work was for (quite) a long time merited in such a way that readers were the ones much more fond of this "Slavonic-Serbian" writer, than analysts of XIX century literature. Such a conclusion was drawn from the results of a detailed analysis of relevant literary-critical and literary-historical works which focused on prose and poetry of one of our most popular pre-Romantic writers. Although Milovan Vidaković acquired his reputation of a talented author due to his novels Ljubomir u Jelisijumu (Vidaković 1814; Vidaković 1817; Vidaković 1823), one should not neglect the fact that Milovan Vidaković is one of the most prolific Serbian pre-Romantic poets, the proof of which is the fact that he published as much as four religious epics (Vidaković 1805; Vidaković 1825; Vidaković 1834; Vidaković 1839). In this study we shall pay special attention to poetical, topical and genre characteristics of his poetic work inspired by Old Testament (Deuterocanonical) story about adventures of Tobias from Nineveh. Relying on my personal research and interpretational experience, I shall try to explain why, in my opinion, no other poetic work of the unfortunate "SlavonicSerbian" polyhistor is that much open to contemporary interpretations as is his "archaic" religious epic Mladi Tovija (Vidaković 1825).

Универзитет у Новом Саду

Филозофски факултет

Одсек за српску књижевност

Др Зорана Ђинђића 2

21000 Нови Сад

rasha@ff.uns.ac.rs 